Check for updates

Cite this as: $B M / 2021 ; 372: n 440$ http://dx.doi.org/10.1136/bmi.n440 Published: 12 February 2021

\title{
Covid-19: Russia's statistics agency reports much higher death toll than country's health ministry
}

\section{Owen Dyer}

Russia's federal statistics service Rosstat has published figures that sharply contradict the number of deaths reported by the country's health ministry.

The latest health ministry figures report 78687 deaths from covid-19 up to February 11 2021. January 2021 has been the pandemic's deadliest month in Russia, with the health ministry reporting over 20 ooo deaths. But Rosstat's figures, published this week, ${ }^{1}$ showed 162429 "coronavirus related fatalities" occurring in Russia in 2020 alone, almost three times higher than the ministry's total figure for 2020 of 57019.

Of the 162429 deaths, 86498 were listed as directly caused by confirmed covid-19, and 17470 were likely caused by the virus, but not confirmed by test. The virus "significantly" contributed to fatal complications of other diseases in 13524 cases, whereas 44937 people died after testing positive for the virus, but it was "not the leading cause of death." The ministry only counts cases in which covid-19 is demonstrated as the cause of death by autopsy.

Rosstat's figures come from morgues and local government death reporting systems. Excess deaths reported by these sources began to streak ahead of health ministry figures last April. Extrapolating the gap between Rosstat's and the health ministry's figures to the present dayindicates covid-19 mortality to date of 1535 per million population, which would place Russia sixth in the world behind San Marino, Belgium, Slovenia, the United Kingdom, and the Czech Republic.

Other figures published recently by Rosstat show that Russia saw 323802 more total deaths from all causes in 2020 than in 2019 , with the excess heavily concentrated at the year's end. In December 2020, Russia recorded 243235 deaths, compared with 149 165 in December 2019. ${ }^{1}$ This toll, combined with lower immigration from former Soviet republics, led to Russia beginning 2021 with a population 510000 smaller than when it began 2020.

Leading figures in the Russian state have conceded the accuracy of Rosstat's figures on excess deaths, including the health minister, Tatiana Golikova. But she continues to defend Russia's practice of attributing some deaths to other causes in people who test positive for the virus, against World Health Organisation advice.

"Unfortunately, the excess mortality in 2020 appeared in nearly every country of the world and it's at levels we wouldn't like to see," Putin's spokesman Dmitry Peskov told reporters. "It's a harsh reality we, all countries of the world, face in the era of the pandemic." Asked to explain the discrepancies in official figures, he said, "As for the incoming data from the regions: there could be peculiarities somewhere."

New cases of covid-19 are now falling in Russia, and restrictions are lifting, although most of the charges against more than 10 ooo people arrested in recent anti-corruption demonstrations involved special pandemic laws meant to enforce social distancing. Government hopes rest on the rollout of the Sputnik vaccine. But despite an early start, only about 2.2 million Russians, about $1.5 \%$ of the population, have been fully or partially vaccinated. Polling indicates that $59 \%$ of Russians plan to avoid taking the vaccine. $^{2}$

Other countries frequently accused of undercounting covid-19 deaths include Turkey, Iran, India, Brazil, Venezuela, and Nicaragua. In Mexico, health officials in October came forward unprompted to say that a review had identified more than 50 ooo unreported covid-19 deaths, at a time when the country was officially reporting 89000 deaths. ${ }^{3}$

If the numbers admitted by the Mexican and Russian governments were added to current global databases-which still show only the lower figures-they would increase the world's death toll by over 150 ooo, to more than 2.5 million deaths.

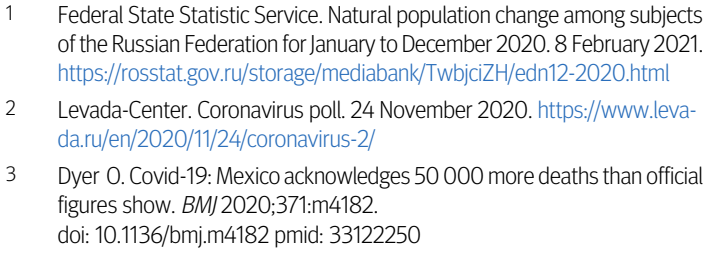

Federal State Statistic Service. Natural population change among subjects of the Russian Federation for January to December 2020. 8 February 2021 https://rosstat.gov.ru/storage/mediabank/TwbjciZH/edn12-2020.html

2 Levada-Center. Coronavirus poll. 24 November 2020. https://www.levada.ru/en/2020/11/24/coronavirus-2/

3 Dyer 0. Covid-19: Mexico acknowledges 50000 more deaths than official figures show. BMJ2020;371:m4182. doi: 10.1136/bmj.m4182 pmid: 33122250

This article is made freely available for use in accordance with BMJ's website terms and conditions for the duration of the covid-19 pandemic or until otherwise determined by BMJ. You may use, download and print the article for any lawful, non-commercial purpose (including text and data mining) provided that all copyright notices and trade marks are retained. 